\title{
Immunological reason for chronic ill health after infectious mononucleosis
}

\author{
T J HAMBLIN, J HUSSAIN, A N AKBAR, Y C TANG, J L SMITH, D B JONES
}

\begin{abstract}
In a group of patients who suffered from chronic ill health after an attack of acute infectious mononucleosis a disorder of $T$ cell regulation was found. By means of cytochemical reactions the staining pattern associated with $T$ suppressor cells was found in a greater percentage and that associated with $T$ helper cells in a smaller percentage than in normal subjects. In a few patients this finding was confirmed in a functional suppressor assay. The patients were unwell for at least a year but most later made a complete recovery, which was associated with return to normal of the lymphocyte subsets.
\end{abstract}

\section{Introduction \\ Infectious mononucleosis is usually an acute infection of short duration without long term effects. Some patients, however, do not fully recover clinically for several months or even years, and there are occasional reports of recurrent cases. ${ }^{1}$ In rare kindreds the infection may progress to a fatal lymphoproliferative disease. ${ }^{2}$ After observing a patient whose infection was complicated by}

\footnotetext{
Department of Haematology, Royal Victoria Hospital, Bournemouth BH1 4JG

T J HAMBLIN, MRCP, MRCPATH, consultant haematologist

Regional Immunology Laboratory, Tenovus Research Institute, Southampton General Hospital, Southampton SO9 4XY

J HUSSAIN, BVMS, research assistant

J L SMITH, PHD, top grade scientific officer

University Department of Pathology, Southampton General Hospital, Southampton SO9 $4 X Y$

A N AKBAR, PHD, research assistant

D B JONES, PHD, lecturer in pathology

Medical School, Southampton General Hospital, Southampton SO9 4XY

Y C TANG, medical student

Correspondence to: $\operatorname{Dr} \mathrm{T} \mathrm{J}$ Hamblin.
}

aseptic meningitis and who relapsed after six months with the same clinical picture from which he failed to make a complete recovery, we assembled a series of patients with chronic ill health after infectious mononucleosis and examined their immune state.

\section{Patients and methods}

We studied 17 patients. One of them (case 1) is described below.

Case 1-A 20 year old motor mechanic presented in June 1978 with sore throat, fever, and cervical lymphadenopathy. Within 24 hours he had developed swollen eyelids, photosensitivity, severe headache, and meningism. He also complained of debilitating malaise and somnolence. His blood film showed many atypical mononuclear cells and the Paul-Bunnell test result was positive. Cerebrospinal fluid contained $20 \times 10^{6}$ lymphocytes/l, and no organism was grown. He was diagnosed as a case of infectious mononucleosis with aseptic meningitis and recovered slowly in hospital without specific treatment. After two months he returned to work but did not feel fully well, even though the Paul-Bunnell test result became negative and his blood film returned to normal. In November 1978 he was readmitted with a similar syndrome. Blood film and result of the Paul-Bunnell test were again diagnostic of infectious mononucleosis and cerebrospinal fluid showed a sterile lymphocytosis. Serum immune complexes measured by polyethylene glycol precipitation showed very high values for IgM containing complexes $(198 \mathrm{mg} / 1$; normal $<20)$. Within two weeks he had recovered enough to be discharged from hospital but he continued to feel unwell. Over the next six months he complained of lethargy, lack of energy, changes in mood, recurrent upper respiratory tract infections, muscle pains, depression, and somnolence. He was unable to return to work.

After consultation with colleagues we identified 16 further patients who had had an attack of infectious mononucleosis from which they had failed to make a complete recovery. Seven patients had had an apparent second attack within one year of the first, showing seroconversion of the Paul-Bunnell test result, which had previously become negative, and all had complained of lethargy and several other symptoms, including myalgia, recurrent upper respiratory tract infections, lymphadenopathy, and inability to return to work. Table I lists the clinical details of all 17 patients, who are designated group 1. None of the other patients had had complications of the infection. In three, concentrations of serum immune complexes had been measured during their initial attack as part of a separate study and none had been excessively high.

To serve as controls 17 patients who had been diagnosed as having 
TABLE I-Clinical features of patients chronically ill after infectious mononucleosis

\begin{tabular}{|c|c|c|c|c|c|}
\hline $\begin{array}{l}\text { Case } \\
\text { No }\end{array}$ & $\begin{array}{c}\text { Sex } \\
\text { and age }\end{array}$ & History of immune defect & Apparent second attack & Symptoms* & Duration \\
\hline $\begin{array}{l}1 \\
2 \\
3 \\
4\end{array}$ & $\begin{array}{l}\text { M } 20 \\
\text { M } 30 \\
\text { F } 26 \\
\text { F } 17\end{array}$ & $\begin{array}{l}\text { Smallpox vaccination-widespread rash. Malaria twice as infant. Asthma as infant } \\
\text { Pneumonia at } 3 / 12 \\
\text { Polyneuritis } 20 \text { years } \\
\text { Severe chickenpox at } 13 \text {, hay fever. Cousins had measles encephalitis. Another }\end{array}$ & $\begin{array}{l}\text { Yes, 6/12 } \\
\text { No } \\
\text { Yes, l year }\end{array}$ & $\begin{array}{l}\text { ACDE } \\
\text { ACDE } \\
\text { ADE }\end{array}$ & $\begin{array}{l}18 \text { months } \\
3 \text { years } \\
10 \text { years }\end{array}$ \\
\hline $\begin{array}{r}5 \\
6 \\
7 \\
8 \\
9 \\
10 \\
11 \\
12 \\
13 \\
14 \\
15 \\
16 \\
17\end{array}$ & $\begin{array}{l}\text { F } 24 \\
F 17 \\
\text { F } 21 \\
\text { M } 21 \\
M 21 \\
M 14 \\
\text { F } 34 \\
\text { M } 17 \\
\text { F } 28 \\
\text { F } 26 \\
\text { F } 18\end{array}$ & $\begin{array}{l}\text { cousin had slow recovery from infectious mononucleosis } \\
\text { Nil } \\
\text { Nil } \\
\text { Nil } \\
\text { Nil } \\
\text { Nil } \\
\text { Nil } \\
\text { Nil } \\
\text { Nil } \\
\text { Nil } \\
\text { Nil } \\
\text { Nil } \\
\text { Nil } \\
\text { Nil }\end{array}$ & $\begin{array}{c}\text { Yes, } 3 / 12 \\
\text { Yes, } 1 \text { year during pregnancy } \\
\text { No } \\
\text { Yes, } 1 \text { year } \\
\text { No } \\
\text { No } \\
\text { Yes, } 6 / 12 \\
\text { No } \\
\text { No } \\
\text { No } \\
\text { No } \\
\text { Yes, } 6 / 12 \\
\text { No } \\
\text { No }\end{array}$ & $\begin{array}{l}\text { ACE } \\
\text { ABC } \\
\text { ABCE } \\
\text { AD } \\
\text { ABE } \\
\text { ACE } \\
\text { ABCDE } \\
\text { ACE } \\
\text { ABE } \\
\text { ABCDE } \\
\text { ABC } \\
\text { AC } \\
\text { ABC } \\
\text { ACE }\end{array}$ & $\begin{array}{l}3 \text { years } \\
2 \text { years } \\
18 \text { months } \\
3 \text { years } \\
18 \text { months } \\
1 \text { year } \\
18 \text { months } \\
1 \text { year } \\
18 \text { months } \\
1 \text { year } \\
18 \text { months } \\
1 \text { year } \\
2 \text { years } \\
1 \text { year }\end{array}$ \\
\hline
\end{tabular}

*A = General malaise. $B=$ Lymphadenopathy. $C=$ Recurrent upper respiratory tract infections. $D=$ Myalgia. $E=$ Inability to return to work.

infectious mononucleosis by full blood count and Paul-Bunnell test six to 12 months previously were called for interview. On the basis of this interview they were divided into 10 who had made a complete recovery from their infection by four months (group 2 ) and seven who had continued to have minor symptoms after four months (group 3). None of the subjects in group 3 had had symptoms as severe as in group 1 ; they complained of recurrent upper respiratory infections and of not attaining their former fitness. Sixteen young healthy laboratory workers served as normal controls (group 4).

Peripheral blood from patients and controls was collected into preservative free heparin. Mononuclear cells were isolated by FicollTriosil gradient sedimentation and then washed three times with buffered Eagle's medium before being resuspended in this medium supplemented with $2^{\circ}$, heat inactivated fetal calf serum at a concentration of $2 \times 10^{9} / 1$. E Rosetting cells were detected by the method of Payne et $a l^{3}$ using non-sensitised red cells from a selected sheep and counting on a Romanowsky stained cytocentrifuge preparation. Cytocentrifuged cell preparations of washed lymphocyte suspensions were dried in air and fixed before staining in a buffered formalinacetone mixture adjusted to $\mathrm{pH} 6.6$ for acid $\alpha$-naphthyl acetate esterase staining and to $\mathrm{pH} 7 \cdot 0$ for acid phosphatase staining. Staining with $\alpha$-naphthyl acetate esterase was by the method of Mueller $e a^{4}{ }^{4}$ and with acid phosphatase by the method of Goldberg and Barka. ${ }^{5}$

The slides were examined independently and blind by two observers and scored for the presence of lymphocytes containing one to four large dots of stain and those containing more than four smaller granules. ${ }^{6}$ Such cells were designated helper and suppressor cells respectively and expressed as a helper:suppressor cell ratio for each patient.

Samples from 11 patients and 21 normal controls were cultured to determine suppressor activity. To do this peripheral blood mononuclear cells $\left(2 \times 10^{9} / 1\right)$ were cultured for 24 hours with and without the mitogen concanavalin A (10 or $20 \mathrm{mg} / \mathrm{l})$. Mitogen induced and control cell populations were then assayed for suppression of immunoglobulin production by normal responder lymphocytes over seven days in culture with pokeweed mitogen. Percentage suppression was calculated by the formula:
No of cytoplasmic immunoglobulin positive cells/well in control culture

\section{No of cytoplasmic}

- immunoglobulin positive cells/well in test culture
No of cytoplasmic immunoglobulin positive cells/well in control cultures

Full details of this assay have been published.?

Statistical comparisons were by the Mann-Whitney test for nonparametric groups. ${ }^{*}$

\section{Results}

Figures 1 and 2 show the $T$ helper: $T$ suppressor cell ratios in the four groups as judged by acid phosphatase and $\alpha$-naphthyl acetate esterase staining. Acid phosphatase staining showed the ratio to be significantly lower in group 1 than in group $2(p<0.001)$, group 3 $(\mathrm{p}<0.05)$, and group $4(\mathrm{p}<0.001)$. Staining with $\alpha$-naphthyl acetate esterase showed a significantly lower ratio in group 1 than in group 2 (p 0.001). Patients in group 3 (who continued to have symptoms after four months) also had significantly more suppressor cells than had the controls $(p-0 \cdot 001)$.
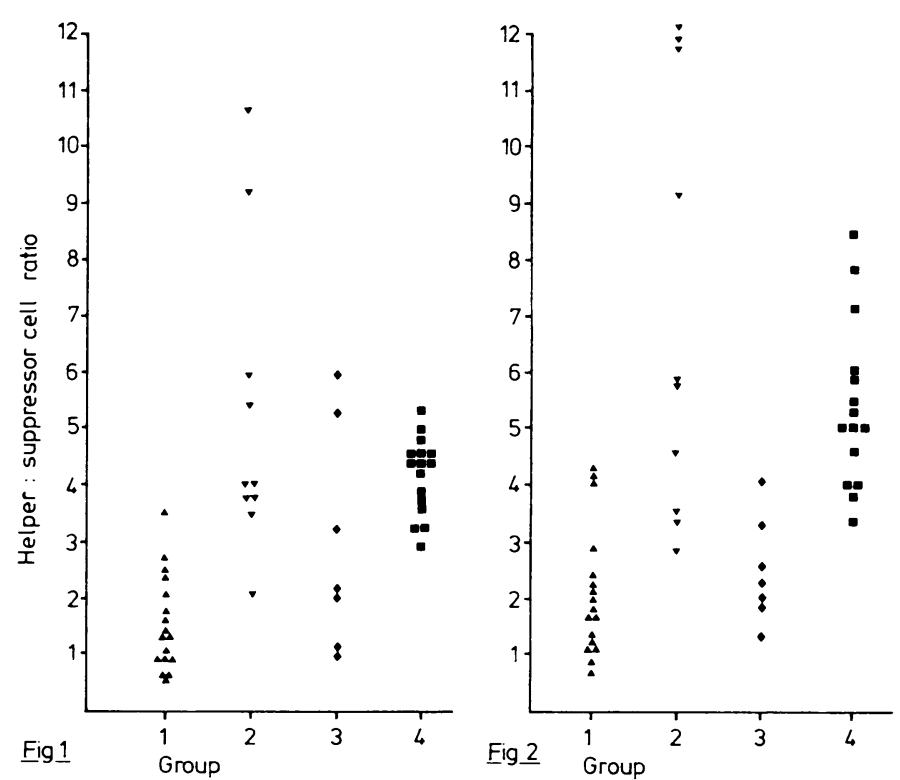

FIG 1-Ratios of $T$ helper: $T$ suppressor cells as determined by acid phosphatase staining in four groups of subjects. (Group 1, patients with chronic ill health; group 2, patients making complete recovery; group 3, patients with minor symptoms; group 4 , healthy controls.)

FIG 2-Ratios of T helper: T suppressor cells as determined by $\alpha$-naphthyl acetate esterase staining in the four groups of subjects.

Two patients (cases 2 and 11) were followed up for eight and nine months, during which time they made a clinical recovery. Analysis of the helper:suppressor cell ratios also showed an improvemen (fig 3).

Cells from four patients in group 1 were tested in an assay of $N$ suppressor activity. Although conconavalin A induced suppressor $D$ activity did not differ significantly from that in controls, all four patients showed significantly greater spontaneous suppressor activity than in 21 normal healthy controls (p.0.01) (table II). One patient

TABLE II-Spontaneous and concanavalin $A(\operatorname{con} A)$ induced suppression of pokeweed mitogen stimulated immunoglobulin synthesis in blood of patients with infectious mononucleosis and healthy controls

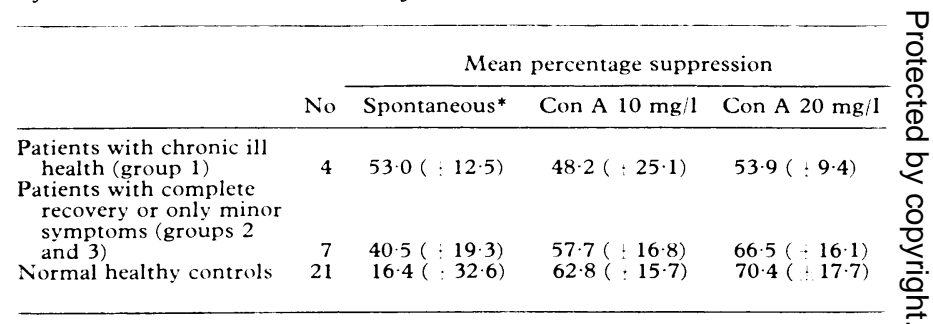

* Mann-Whitney test for non-parametric groups: group 1 versus healthy controls, n. $0.01 ;$ groups 2 and 3 versus healthy controls, Ns.

\section{,}


(case 11) was retested when he had made a complete recovery and his helper:suppressor cell ratio had returned to normal. At the time his spontaneous suppressor activity also fell from $50 \cdot 3 \%$ to $28.0 \%$.

Cells from seven patients from groups 2 and 3 who had made a complete recovery from infectious mononucleosis or had suffered only minor symptoms after four months were also tested in this assay. Neither conconavalin A induced nor spontaneous suppressor activity differed significantly from that in controls.

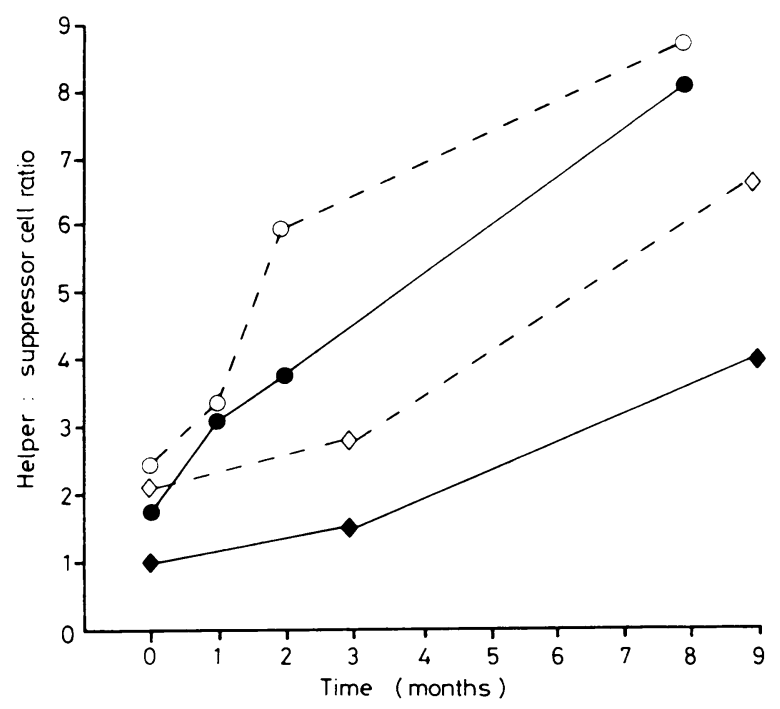

FIG 3-Improvement in $\mathrm{T}$ helper: $\mathrm{T}$ suppressor cell ratios with time in cases $2(0 \bigcirc)$ and $11(\diamond \diamond)$. (Solid symbols and lines designate results with acid phosphatase staining. Open symbols, broken lines designate results with $\alpha$-naphthyl acetate esterase staining.)

\section{Discussion}

Peripheral blood $\mathrm{T}$ cells are divided into two major subtypes. T helper/inducer cells bear Fc $\mu$ receptors, ${ }^{9}$ react with the monoclonal antibody OKT4, ${ }^{1 "}$ show a prominent single or at most three dot positivity with acid phosphatase or $\alpha$-naphthyl acetate esterase staining, ${ }^{6}$ and are necessary in in vitro cultures of $\mathrm{B}$ cells to stimulate antibody production. ${ }^{11} \mathrm{~T}$ suppressor/ cytotoxic cells bear $\mathrm{Fc} \gamma$ receptors, ${ }^{9}$ react with monoclonal antibodies OKT 5 and $8,{ }^{11}$ show granular positivity with acid phosphatase or $\alpha$-naphthyl acetate esterase staining, ${ }^{6}$ and have a suppressive effect on immunoglobulin production by $B$ cell cultures."

These various methods do not show complete correlation. In particular, cytochemical staining tends to underestimate the number of $T$ suppressor cells; thus although we chiefly used cytochemical staining as an assay of helper and suppressor cells, in individual patients we used a functional assay as a check on our findings. We have shown clearly that in a group of patients who failed to make a complete recovery from infectious mononucleosis high levels of $\mathrm{T}$ suppressor cells were found. Moreover, in the two patients in whom we observed clinical recovery over nine months $T$ suppressor cell levels declined. The high levels of $T$ suppressor cells were reflected in the degree of spontaneous suppressor activity found in the chronically ill patients. Other workers have found that recovery from acute infectious mononucleosis is associated with a decline in spontaneous suppressor activity, $,^{12} 1: 3$ and in one of our patients (case 11) the clinical improvement coincided with a decline in suppressor activity towards normal.

In infectious mononucleosis the initial infection of $\mathrm{B}$ cells by Epstein-Barr virus is followed by an extensive proliferation of $\mathrm{T}$ cells which are cytotoxic for lymphoid cells infected by EpsteinBarr virus ${ }^{14}$ and in addition suppress autologous $T$ cell proliferation to antigens as well as $\mathrm{B}$ cell immunoglobulin production stimulated by pokeweed nitrogen. ${ }^{15}$ They have been characterised at $T$ suppressor/cytotoxic cells by the monoclonal antibody OKT8. ${ }^{16}$ These proliferating $\mathrm{T}$ cells are thought to have a major role in the self limiting nature of infectious mononucleosis and to be responsible for the reduction of numbers of EpsteinBarr virus infected lymphocytes in the blood from one in 2000 at the end of the first week of the illness to five in 10 at three months. ${ }^{17}$ In normal people the virus then becomes latent, resembling other herpes viruses in this respect.

When this system of $\mathrm{T}$ cell control breaks down there are serious consequences. A sex linked inheritance of failure to mount an effective $T$ cell response to Epstein-Barr virus infected $B$ cells may lead to a fatal polyclonal lymphoproliferative disease, ${ }^{2}$ and patients given cyclosporin $\mathrm{A}$-which damages activated $\mathrm{T}$ cells and promotes a spontaneous outgrowth in vitro of EpsteinBarr virus induced B cell lines ${ }^{18}$ - may develop an Epstein-Barr virus related, lymphoma like syndrome. ${ }^{19}$

Lymphoproliferation may occur in other similar circumstances and, although true monoclonal lymphomas are rare, ${ }^{20}$ polyclonal lymphoproliferation may be equally fatal. ${ }^{2}$

None of our patients had been as severely ill as that, but their morbidity and time lost from work had nevertheless been considerable. Furthermore, we were probably detecting only a small proportion of the ill health that occurs after infectious mononucleosis, since of the 17 control patients who had had the infection in the previous 12 months, seven complained of symptoms persisting for longer than four months. This may, of course, have been a self selected group, since several of those invited to attend for interview did not reply. Seven of our patients had apparently had second attacks of the infection in that their Paul-Bunnell test results, which had become negative, became positive again at a time when symptoms returned together with an atypical lymphocytosis. It is difficult to envisage how this could happen and quite possibly these second attacks were, in fact, caused by other viruses which produced an anamnestic response in the heterophile antibody titre.

Tobi et $a l^{21}$ have reported a series of seven patients in whom there was serological evidence of persisting Epstein-Barr virus infection. Their patients bore some resemblance to those in our series in that malaise, lymphadenopathy, and myalgia were prominent but other features that they noticed-particularly fever, weight loss, and lymphocytosis-were not present in our group. We have no serological measurements to compare with their series, and they have no data on $\mathrm{T}$ cell subsets to compare with ours.

One explanation for our findings might be that the infected $B$ cells, unable to produce an effective specific $T$ cell suppression, induce an overactive non-specific $\mathrm{T}$ cell suppression which impairs the patient's reaction to other viral infections and releases inflammatory mediators which give the symptoms of ill health.

The recent finding of sustained $\mathrm{T}$ suppressor cell activity in the $\mathrm{X}$-linked lymphoproliferative syndrome ${ }^{22}$ supports our hypothesis and emphasises the need for an intact $T$ cell regulatory system for the normal evolution of infectious mononucleosis.

We are grateful to Dr C J Moran, who helped to draw our attention to this problem, referred his patients for us to study, and discussed the problem with us in a most stimulating manner.

\section{References}

${ }^{1}$ Chang RS, Maddock R. Recurrence of infectious mononucleosis. Lancet $1980 ; \mathrm{i}: 704$.

${ }^{2}$ Purtillo DT, De Florio D, Hutt LM, et al. Variable phenotypic expression of an X-linked recessive lymphoproliferative syndrome. $N$ Engl $\mathcal{F}$ Med $1977 ; 297: 1077-81$.

${ }^{3}$ Payne SV, Smith JL, Jones DB, Wright DH. Lymphocyte markers in non Hodgkin's lymphoma. Br f Cancer 1976;36:57-64.

${ }^{4}$ Mueller J, Brun del Re G, Buerki H, Keller HV, Hess MW, Coutier H. Non specific acid esterase activity: a criterion for differentiation of $\mathrm{T}$ and B lymphocytes in mouse lymph nodes. Eur 7 Immunol 1975;5:270-4.

${ }^{5}$ Goldberg AF, Barka T. Acid phosphatase activity in human blood cells. Nature 1962;195:297.

${ }^{6}$ Bevan A, Burns GF, Gray L, Cawley JC. Cytotoxicity of human T cell population. Scand f Immunol 1980;11:223. 
${ }^{7}$ Lobo PI, Spencer CI. Inhibition of humoral and cell mediated responses in man by distinct suppressor cell systems. $\mathcal{f}$ Clin Invest 1979;63:1157.

${ }^{8}$ Seigel S. Non parametric statistics for the behavioral sciences. New York: McGraw-Hill, 1956:95-158.

${ }^{9}$ Moretta L, Webb S, Grossi CE, Lydyard PM, Cooper MD. Functional analysis of two human lymphocyte populations: help and suppression of $\mathrm{B}$ cell responses by $\mathrm{T}$ cells bearing receptors for IgM or IgG. F Exp Med 1977;146:184-200.

${ }^{10}$ Kung PC, Goldstein G, Reinherz EL, Schossman SF. Monoclonal antibodies defining distinctive human $\mathrm{T}$ cell surface antigens. Science $1979 ; 206: 347-9$

${ }^{11}$ Ishizaka K, Adachi T. Generation of specific helper cells and suppressor cells in vitro for the IgE and IgG antibody responses. 7 Immunol 1976; 117:40-7.

12 Johnsen HE, Madsen M, Kristensen T. Lymphocyte sub populations in man: suppression of PWM induced $\mathrm{B}$ cell proliferation by infectious mononucleosis T cells. Scand f Immunol 1979;10:251-5.

${ }^{13}$ Haynes BF, Schooley KT, Payling Wright CK, Grange JE, Dolin R, Fauci AS. Emergence of suppressor cells of immunoglobulin systems during acute Epstein Barr virus induced infectious mononucleosis. f Immunol 1979;123:2095-101.

${ }^{14}$ Royston I, Sullivan JL, Perriman PO, Perlin E. Cell-mediated immunity to Epstein Barr virus transformed lymphoblastoid cells in acute infectious mononucleosis. N Engl f Med 1975;293:1159-63.
15 Tosato G, Magrath I, Koski I, Dooley N, Blaese M. Activation of suppressor $\mathrm{T}$ cells during Epstein Barr virus induced infectious mononucleosis. $N$ Engl f Med 1979;301:1133-7.

${ }^{16}$ Reinherz EL, O'Brien C, Rosenthal P, Schlossman SF. The cellular basis for viral induced immunodeficiency: analysing monoclonal antibodies. F Immunol 1980;125:1269-4.

17 Anonymous. Limited immunodeficiency, Lancet 1978;i:132-3.

${ }_{18}$ Bird AG, McLachlan SM, Britten S. Cyclosporin A promotes spontaneous outgrowth in vitro of Epstein Barr virus induced B cell lines. Nature $1981 ; 289: 300-1$

19 Crawford DH, Thomas JA, Janossy G, et al. Epstein Barr virus nuclear antigen positive lymphoma after cyclosporin $A$ treatment in a patient with renal allograft. Lancet $1980 ; \mathrm{i}: 1355-6$

20) Abu W, Tokada K, Kamada $M$, et al. Evolution of infectious mononucleosis into Epstein Barr virus carrying monoclonal malignant lymphoma. Lancet 1982; : $: 1272-5$.

21 Tobi M, Morag A, Ravid Z, et al. Prolonged atypical illness associated with serological evidence of persistent Epstein Barr virus infection. Lancet 1982; :61-4.

${ }^{22}$ Lindsten T, Selley JK, Ballow M, et al. Immune deficiency in the X-linked lymphoproliferative syndrome II. Immunoregulatory $\mathrm{T}$ cell defects. f Immunol $1982 ; 129: 2536-40$.

(Accepted 7 April 1983)

\title{
Factors predictive of attendance at clinic and blood pressure control in hypertensive patients
}

\author{
P DEGOULET, JMENARD, H-A VU, J-L GOLMARD，C DEVRIES，G CHATELLIER, P-F PLOUIN
}

\begin{abstract}
Poor compliance with appointments and drug treatment is one of the recognised factors preventing effective management of hypertension. Factors predictive of poor attendance and inadequate blood pressure control in patients attending a hypertension clinic were therefore determined using univariate analyses and a multivariate logistic model. Out of 1346 patients with blood pressure exceeding $160 / 95 \mathrm{~mm} \mathrm{Hg}$ followed up for three years, $209(15.5 \%)$ dropped out during the first year. Variables that were significantly related to increased drop out rates were male sex, young age, obesity at entry, cigarette smoking, direct referral to the clinic as a result of screening instead of referral by a general practitioner, absence of pre-existing antihypertensive treatment at the first visit, moderate hypertension, and low socioeconomic category. Variables at entry that were significantly related to poor blood pressure control at one year were old age, evidence of coronary heart disease, severe hypertension, and raised blood glucose concentrations.
\end{abstract}

Early detection of patients at high risk of drop out or

Medical Informatics Department and INSERM U194, Hôpital

Pitié-Salpétriè, e 75634 Paris Cédex 13

$P$ DEGOULET, $M D, M S C$, senior lecturer in medical informatics

J-L GOLMARD, MD, lecturer in statistics

C DEVRIES, MD, programme analyst

Hypertension Clinic, Hôpital Broussais, Paris

J MENARD, MD, MSC, associate professor and head of clinic

$\mathrm{H}-\mathrm{A}$ VU, MD, research fellow in medical informatics

G CHATELLIER, MD, research fellow in epidemiology

Hypertension Clinic, Hôpital Saint-Joseph, Paris

P-F PLOUIN, MD, head of clinic

Correspondence to: Dr P Degoulet poor blood pressure control might improve treatment of hypertension and allow management to be more individually adapted to each patient.

\section{Introduction}

In everyday practice the results of medical treatment for permanent arterial hypertension are often considerably poorer than expected. This lack of success is possibly due to inadequate screening to detect hypertension, poor or delayed access to care, inadequate treatment, and, finally, low compliance with drug treatment. ${ }^{1}$ Efforts to improve screening for hypertensive disease and the distribution of care, however, are useless and $\exists$ costly to the community if compliance is poor. ${ }^{2}$

The reasons for poor compliance are numerous. Hypertension is often asymptomatic and may necessitate lifelong treatment that is costly and sometimes poorly tolerated. Improving compliance requires the combined efforts of both the patient $O$ and the doctor. ${ }^{3}$ In this study we determined the risk factors $D$ present at the first visit associated with low compliance with appointments and poor treatment results in hypertensive $\tilde{O}$ patients attending the Saint-Joseph Hospital hypertension clinic N between January 1976 and December 1978 and enrolled in the 0 computerised Artemis system." The methods adopted in this prospective study were similar to those used for predicting fatal or non-fatal cardiovascular complications in cohort studies. ${ }^{56} \stackrel{\infty}{\rightarrow}$ We considered that early detection of patients at high risk of 0 dropping out ${ }^{3}$; might improve the management of patients with hypertension.

Patients and methods

STUDY POPULATION

Between 1 January 1976 and 31 December 1978, 2920 patients $\frac{0}{7}$ were referred to the hospital's outpatient hypertension clinic. Altogether 1346 records were analysed and selected by according to two 